\title{
Ukrainian Orthodox Church Autocephaly and its Ecumenical Consequences
}

At the end of August 2018 in Kiev an Inter-Religious Prayer was held in the presence of the Ukrainian President and different dignitaries of the state. The Heads of all the divided Orthodox Churches (Ukrainian Orthodox Church Moscow Patriarchate, Ukrainian Orthodox Church Kiev Patriarchate, Ukrainian Autocephalous Church), the Roman Catholic and the Greek Catholic Churches, the Protestant, Jewish and Muslim communities attended this special moment praying for peace and for their country. Short prayers were given by His Beatitude Filaret - Primate of the Ukrainian Orthodox Church (Kiev Patriarchate), His Beatitude Onufriy - Primate of the Ukrainian Orthodox Church, Moscow Patriarchate, His Beatitude Svyatoslav Shevchuk - of the Ukrainian Greek Catholic Church, His Grace Vitaliy Krivitsky of the Kiev Diocese of the Roman Catholic Church; the Chief Rabbi Yakov of Kiev and Ukraine, Mufti Tamim Ahmed - of the Spiritual Directorate of Muslims of Ukraine, and Gregory Commandant - president of the Ukrainian Bible Society, representing the Evangelical communities in Ukraine. What was very interesting about this moment was not only the fact that representatives of different religious denominations were praying in the same place for peace but the context in which this moment took place. All those present were aware of the question of the Ukrainian Orthodox Church Autocephaly and certainly some of them did not have the same opinion about this complex issue. In the same time there was a sign of hope and that came with the power of so many prayers belonging to different religious traditions.

\section{Ukrainian Petition to the Patriarch of Constantinople}

On April 19, 2018, the Ukrainian Parliament voted for a resolution to appeal to the Ecumenical Patriarch Bartholomew I on the provision of the Tomos of Autocephaly to the Orthodox Church in Ukraine. A few days later, Ukrainian President Petro Poroshenko said that the Ecumenical Patriarchate had initiated the procedures necessary to grant autocephaly to the Orthodox Church in Ukraine. President Poroshenko visited the Ecumenical Patriarchate's Headquarters at the Phanar in Istanbul on April 9, 2018. Only ten days later The Synod of the Patriarchate of Constantinople discussed the situation of the Ukrainian Orthodox and the conclusions were published with a Communique of the Synod on the $22^{\text {nd }}$ of April : "In accordance with the 
Divine and Sacred Canons, as well as centuries-old ecclesiastical order and Holy Tradition, the Ecumenical Patriarchate concerns itself with the preservation of Pan-Orthodox unity and the care for the Orthodox Churches throughout the world - especially of the Ukrainian Orthodox Nation that has received the salvific Christian faith and holy baptism from Constantinople. Thus, as its true Mother Church, it examined matters pertaining to the ecclesiastical situation in Ukraine, as done in previous synodal sessions, and having received from ecclesiastical and civil authorities - representing millions of Ukrainian Orthodox Christians - a petition that requests the bestowal of autocephaly, decided to closely communicate and coordinate

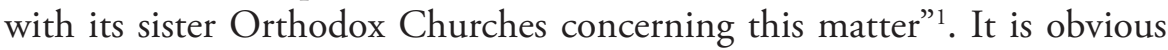
from this Document that The Patriarch of Constantinople and His Synod want to underline the reasons for discussing the religious situation in Ukraine: Orthodox unity, care for the Ukrainian Orthodox reminding the origin of Christianity in Kiev (The Baptism of the Rus' in 988) and Constantinople as Mother Church. In the same time there had been a Petition made by Ukrainian civil authorities and also by Ecclesiastical authorities requesting the Autocephaly. Nevertheless, the Patriarchate of Constantinople seemed ready to have a dialogue with the other Orthodox Churches regarding this issue. Who were the ecclesiastical authorities who signed this Petition? Knowing the opposition of the Russian Orthodox Church to the intervention of the Patriarchate of Constantinople in this matter it is obvious the Head of the Church opposed this Petition too and a good number of the Bishops of the same jurisdiction in Ukraine seemed to have exactly the same attitude. Those openly in favour of the Autocephaly were the Bishops of the Ukrainian Orthodox Church Kiev Patriarchate and of the Ukrainian Autocephalous Orthodox Church but these two Churches were not considered canonical in April 2018 and were not recognized by any Orthodox Church including Constantinople. Certainly the Petition was signed by Bishops and clergy of the Ukrainian Orthodox Church Moscow Patriarchate but in opposition with the Head of this Church. After almost 30 years of division among Orthodox in Ukraine (after the proclamation of independence of 1991) this was a new attempt to solve the problem and bring unity. In the same time, it was only the beginning of a process that had to include dialogue between the three different Orthodox jurisdictions in Ukraine and between the Patriarchate of Constantinople and the Russian Orthodox Church.

\footnotetext{
1 "Communique of the Holy and Sacred Synod of the Ecumenical Patriarchate (22.04.2018)". See: http://www.ec-patr.org/docdisplay.php?lang=en\&id=2475\&tla=gr, viewed on October 25, 2018.
} 


\section{Dialogue Between the Ecumenical Patriarchate and the Russian Orthodox Church}

On the $31^{\text {st }}$ of August 2018, the Ecumenical Patriarch Bartholomew met a delegation of the Russian Orthodox Church leaded by Patriarch Kirill. The discussion was focused on the situation of Ukraine and the division among the Orthodox in this country. At this point it was rather clear that the Ecumenical Patriarch saw this complex issue as an important matter for Constantinople and did not want to refuse the Petition received in April. From the point of view of the Russian Orthodox Church, Ukraine was a part of its canonical territory and the only canonical Church in the country was the one under its jurisdiction and did not officially ask for autocephaly. The two different views on the matter would develop soon into a very difficult dialogue.

\section{Exarchs Appointed by the Ecumenical Patriarchate in Ukraine}

On the $2^{\text {nd }}$ of September 2018, the Bishops' Council in Constantinople decided the Ecumenical Patriarch could grant autocephaly without the consent of other Orthodox Churches. On the $7^{\text {th }}$ of September the Ecumenical Patriarch made a new step towards the autocephaly of the Orthodox Church in Ukraine appointing as His two Exarchs in Kiev Archbishop Daniel of Pamphilon from the United States, and Bishop Ilarion of Edmonton from Canada, both of whom are presently serving the Ukrainian Orthodox faithful in their respective countries under the Ecumenical Patriarchate. The role of the Exarchs was to represent the Ecumenical Patriarchate in the dialogue with Ukrainian Orthodox Churches but mainly to encourage the dialogue between these three Churches in the framework of the future autocephaly. This decision was not accepted by the Russian Orthodox Church, being considered an anticanonical decision and was strongly condemned. Autonomous Churches under the jurisdiction of the Russian Orthodox Church (The Russian Orthodox Church Outside of Russia, Belarusian Orthodox Church and Ukrainian Orthodox Church Moscow Patriarchate) publicly condemned the decision of the Ecumenical Patriarchate as well. The Ukrainian Orthodox Church Moscow Patriarchate refused to meet the two Exarchs. The other two Orthodox Churches' Bishops as well as the Ukrainian President met and welcomed them.

\section{Decisions Taken by the Ecumenical Patriarchate on the 11th of October}

Between the $9^{\text {th }}$ and the $11^{\text {th }}$ of October 2018 the Holy Synod of the Ecumenical Patriarchate took very important decisions regarding Ukraine establishing the Stavropegion of the Ecumenical Patriarch in Kiev, one of its 
many Stavropegia in Ukraine that existed there always and changing the canonical status of the Orthodox Church in the country and reversing a very much-debated Synodal Letter of 1686 "which granted the right through oikonomia to the Patriarch of Moscow to ordain the Metropolitan of Kiev, elected by the Clergy-Laity Assembly of his eparchy, who would commemorate the Ecumenical Patriarch as the First hierarch at any celebration, proclaiming and affirming his canonical dependence to the Mother Church of Constantinople"2. Such a decision meant that Ukraine had always been considered as canonical territory of the ecumenical Patriarchate and even the rights given more than three centuries ago to Moscow were revoked. If all the Byzantine tradition Churches in Ukraine (the three Orthodox Churches and the Greek-Catholic Church) recognize the role of Constantinople in the Baptism of the Rus' hardly all of them considered the Synodal Letter of 1686 as just a provisional act and the Ukrainian Orthodox Church - Moscow Patriarchate certainly considers that act as a recognition of the Metropolis of Kiev as part of the Russian Orthodox Church.

A second Decision of the same Synod would try to solve the canonical status of the Heads of the two Orthodox Churches that had been considered non-canonical until then. Filaret Denisenko, who was Metropolitan of Kiev after the fall of communism and now leads the Ukrainian Orthodox Church - Kiev Patriarchate, and Makariy Maletych, who leads the Ukrainian Autocephalous Orthodox Church, and their followers were canonically reinstated to their hierarchical or priestly rank, and their faithful have been restored to communion with the Church. One of the reasons for this decision was the lack of dogmatic issues regarding these Hierarchs, clergy and followers. The consequences of such a decision are evident: the Ecumenical Patriarchate does not consider anymore those that belong to these two Orthodox jurisdictions in Ukraine as being "in schism" and their Sacraments can't be doubted. They can now all be part of the process of unification of the Ukrainian Orthodoxy. It is important to emphasize, though, that the Ecumenical Patriarchate did not refer to the Head of the Ukrainian Orthodox Church Kiev Patriarchate giving the title of Patriarch and probably one of the reasons is to encourage the dialogue of all three Orthodox jurisdictions in Ukraine. The future Council of the unified Church will elect the Head of the Church, who will receive the Tomos of Autocephaly from the Ecumenical Patriarchate.

There was a very sensitive point in the decisions taken by the Synod on the $11^{\text {th }}$ of October 2018 and that was regarding the properties of the different Orthodox jurisdictions in Ukraine. The Synod made an appeal to

\footnotetext{
2 "Announcement of the Holy and Sacred Synod (11/10/2018)". Available online: https:// www.patriarchate.org/-/communiq-1, viewed on November 2, 2018.
} 
all sides involved that they avoid appropriation of Churches, Monasteries and other properties, as well as every other act of violence and retaliation. Hopefully this appeal will be listened by all and tensions similar to those between Greek-Catholics and Orthodox in Ukraine almost 30 years ago (for the churches, monasteries confiscated by the Soviets in 1946 from the Greek-Catholics and given to the Russian Orthodox Church) won't repeat now between different Orthodox jurisdictions.

\section{Russian Orthodox Church Breaks Communion with the Ecumenical Patriarchate}

A reaction of the Russian Orthodox Church to the Decisions of the Ecumenical Patriarchate came very quickly and as expected it was not a positive one. The Synod of the Russian Orthodox Church met in Minsk, the capital of Belarus, and condemned what was called as an "encroachment of the Patriarchate of Constantinople on the canonical territory of the Russian Orthodox Church"3. The Eucharistic communion was no longer considered possible, there will be no more concelebrations with the clergy of Constantinople and even the laity could not receive the Sacraments in the churches of the Patriarchate of Constantinople. The situation seemed this time more serious than the one regarding the canonical status of the Estonian Orthodox Church. The Russian Orthodox Church also made an appeal to the Heads of the other Orthodox Churches to evaluate the situation and jointly search for ways out of the crisis.

\section{Reaction of Some Orthodox Churches to the Situation in Ukraine}

Already on the $30^{\text {th }}$ of September (a few days before the decisions of the Ecumenical Patriarch) Patriarch Theodore of Alexandria and All Africa, after performing the rite of great consecration of the Holy Transfiguration Cathedral in the city of Bolgrad, His Beatitude noted in his homily that he had come to Ukraine to show his love and that the Ukrainian Orthodox Church is the only canonical Church in Ukraine. The Patriarch underlined the importance of the Apostolic canons in the Church, and the canonical Church is guided by the canons.

The Bulgarian Orthodox Church discussed the situation in Ukraine during the meeting of its Synod on October 4, 2018, and considered the Letter of October 3, 2018, from Patriarch Kirill of Moscow and All Russia concerning the situation in Ukraine. After the letter was read out, various

\footnotetext{
3 "Statement by the Holy Synod of the Russian Orthodox Church concerning the encroachment of the Patriarchate of Constantinople on the canonical territory of the Russian Church". Available online: https://mospat.ru/en/2018/10/15/news165263/, viewed on November 2, 2018 .
} 
opinions were expressed in the course of a discussion. Only Bishops of the Synod openly criticized the decisions taken by the Ecumenical Patriarchate considering Ukraine as canonical territory of the Russian Orthodox Church. The majority of the Synod did not join them in these considerations and the Synod kept a rather neutral stance ${ }^{4}$.

The Patriarch of Antioch visited the Serbian Orthodox Church and gave a common statement with its Patriarch on the $19^{\text {th }}$ of October. The two Heads of Churches expressed their great concern about the dangers of estrangement, division and separation that threatened the Local Autocephalous Orthodox Churches and believed these were a result of "unilateral decisions which are impacting the basis of consensus and of fraternal relations between these Churches". At the end of the Statement it was said: "The dangerous situation in the Orthodox world, resulting from the situation in Ukraine, cannot continue without ultimately establishing a lasting division between all the members of the Orthodox Church. That is detrimental to the peace bond in the Orthodox pleroma and to its testimony in today's world. Therefore, and given the urgent need to avoid further escalation in the current crisis, the Serbian and Antiochian Patriarchs appeal to their brother, His All Holiness the Ecumenical Patriarch, to restore the fraternal dialogue with the Orthodox Church of Russia in order to, with the fraternal assistance and participation of all the other primates of the Local Orthodox Autocephalous Churches, resolve the conflict between the Patriarchates of Constantinople and Moscow and to restore the bond of peace in the Orthodox Church"6.

The Romanian Orthodox Church met at the end of October 2018 and discussed the situation in Ukraine reiterating its recommendation of May 24, 2018 for the Ecumenical Patriarchate and the Moscow Patriarchate to arrive at a solution together, while preserving unity of faith and administrative-pastoral freedom, the latter representing a characteristic feature of Orthodoxy. The Synod underlined the fact that unity was preserved through co-responsibility and cooperation between the Local Orthodox Churches, by cultivating dialogue and synodality at the pan-Orthodox level ${ }^{7}$.

4 "Three hierarchs of Bulgarian Orthodox Church make statement on situation in Ukraine", https://mospat.ru/en/2018/10/12/news165075/, viewed on November, 2, 2018.

5 "Joint Statement of the Serbian and Antiochian Orthodox Patriarchates". http://www. spc.rs/eng/joint_statement_serbian_and_antiochian_orthodox_patriarchates, viewed on November 2, 2018.

6 "Joint Statement of the Serbian and Antiochian Orthodox Patriarchates". http://www. spc.rs/eng/joint_statement_serbian_and_antiochian_orthodox_patriarchates, viewed on November 2, 2018.

7 Biroul de Presă al Patriarhiei Române, "Ce hotărâri au adoptat ierarhii români reuniți în Sinod”, http://basilica.ro/ce-hotarari-au-adoptat-ierarhii-romani-reuniti-in-sinod/, viewed on November 3, 2018. 
No Orthodox Church followed the Russian Orthodox Church in breaking communion with the Ecumenical Patriarchate even if it is obvious that all of them encourage dialogue and fear the consequences for the unity among Orthodoxy.

\title{
Ecumenical Consequences of the Situation in Ukraine
}

It is important to emphasize that it is not up to the different Western Churches or to the Oriental Orthodox Churches to intervene in a difficult situation that is an internal affair of the Orthodox Churches.

In the same time the International Commission of Dialogue Between the Catholic Church and the Orthodox Church will be affected because it will probably be difficult to have all the Orthodox Churches participate in the Commission given the current situation. All the other ecumenical bodies could also be affected.

The Ukrainian Greek-Catholic Church certainly follows the current situation but remains faithful to the position of the Holy See that this is an internal affair of the Orthodox Churches. As another Heir to the ancient Metropolis of Kiev, this Oriental Catholic Church is certainly the most interested in a solution for its Orthodox brothers.

\section{The Future Tomos}

The last part of the framework of the Ukrainian Autocephaly is following these coming weeks. Will the Council summoned by the Ecumenical Patriarch convince the Bishops of the Ukrainian Orthodox Church Moscow Patriarchate to attend and be part of It? Will the other two Orthodox jurisdictions find common ground for the issues like the name of the future Church? Will religious freedom be fully respected for those that will not want to join the new unified Church? How will the relations between the Russian Orthodox Church and the Ecumenical Patriarchate evolve after the Council and the Tomos?

The only thing all Christians can do now is pray that dialogue and peace will prevail, and the unity of Christians won't be affected again.

\author{
Fr. Coriolan Mureșan ${ }^{*}$ \\ Doctor in Oriental Canon Law
}

\footnotetext{
${ }^{*}$ Fr. Dr. Coriolan Mureșan, Greek-Catholic Church Dublin, Presbitery 2, Saint Josef Road, Dublin, (0035) 312447995, coryolan26@yahoo.it
} 